\title{
Spítalinn okkar ALLRA
}

\section{Porkell}

\section{Sigurlaugsson}

framkvæmdastjóri fjármála og fasteignareksturs $\mathrm{HR}$, stjórnarmaður í Spítalanum okkar, landssamtaka um uppbyggingu nýs húsnæðis Landspítala

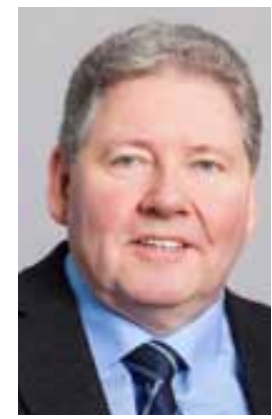

„Spítalinn okkar", landssamtök um uppbyggingu nýs húsnæðis Landspítala voru stofnuð 9. apríl 2014 og voru stofnendur í upphafi 300, en eru nú orðnir um 500 og fjölgar stöðugt. Ég purfti ekki að hugsa mig tvisvar um pegar Jóhannes M. Gunnarsson fyrrverandi framkvæmdastjóri lækninga á Landspítala bað mig að koma í stjórn pessara samtaka. Anna Stefánsdóttir, fyrrverandi hjúkrunarforstjóri Landspítala, er formaður samtakanna. Ég vildi gjarnan leggja pessu lið sem viðskiptafræðingur og með mikla reynslu sem próunaraðili og verkefnastjóri Háskólans í Reykjavík (HR) við nýbyggingu hans við Nauthólsvík. Áđur starfaði HR á fjórum stöðum með öllu pví óhagræði sem pví fylgdi og samskiptaleysi milli starfsmanna. Erfitt var að byggja upp heilsteyptan starfsmannaanda og pjónustu við nemendur. Reynsla mín af heilbrigðiskerfinu sem „,viðskiptavinur“ er par til viðbótar nokkur.

Hlutverk Spitalans okkar er fyrst og fremst að fylkja okkur á bak við petta verkefni og styðja landsmenn við að koma pví í framkvæmd. Sífellt fleiri eru að átta sig á mikilvægi pess að hefja sem fyrst endurnýjun húsnæðis Landspítala. Brýnast er að reisa meðferðarkjarna og rannsóknarhús.

Vel hefur verið staðið að parfagreiningu og frumhönnun nýrrar Landspítalabyggingar. Með frestun framkvæmda er verið að ýta vandanum á undan sér og eftir pví sem árin líða er hætta á að nauðsynleg reynsla og pekking á pessu flókna verkefni glatist. Ég pekki pað af eigin reynslu eftir að hafa starfað sem verkefnastjóri við parfagreiningu, hönnun og framkvæmdir nýbyggingar HR frá 2006 til 2010. Par skipti samfella og sterk samstaða miklu máli og ekki síður fjárhagslegur bakhjarl. Á rúmlega fjórum árum tókst að ljúka parfagreiningu og hanna og byggja 30.000 fermetra háskólabyggingu.

Pví miður var samdráttartímabil áranna 2009-2013 ekki nýtt til að ljúka hönnun og hefja framkvæmdir við Landspítala. Ekki bólar enn á framhaldi verkefnisins. Vissulega skiptir máli að opnað hefur verið aðeins á verkefnið og fjármunir hafa verið settir í fullnaðarhönnun sjúkrahótels í tveimur síðustu fjárlagafrumvörpum. Sjúkrahótel er mikilvæg framkvæmd, en pað er ekki upphaf að nauðsynlegri uppbyggingu meðferðarkjarna og rannsóknaraðstöðu Landspítala. Petta er fyrst og fremst sérhæft hótel eins og nafnið ber með sér og hefði pess vegna mátt fara í einkaframkvæmd.

Heilbrigðiskerfið, bæði rekstur Landspítala og heilbrigðisvísindasvið Háskóla Íslands, hafa á undanförnum áratugum pótt til fyrirmyndar hér á landi. Við megum ekki bíða eftir að vandamálin vaxi okkur svo yfir höfuð að velferð landsmanna sé í húfi. Smátt og smátt hellast yfir okkur vandamál sem brýn pörf er á að leysa:

- Pjóðin er að eldast og pað kallar yfir okkur á næstu 10-15 árum stóran hóp eldri borgara sem purfa mikla læknispjónustu og vaxandi fjöldi ferðamanna bætist einnig við pann hóp.

- Húsnæði og tækjabúnaður mætir víða ekki pörfum pjónustunnar og pað torveldar mjög að íslenskir sérfræðingar snúi heim að loknu sérnámi erlendis.

- Rekstur heilbrigðiskerfisins er dýrari og óhagkvæmari vegna dreifðrar starfsemi í óhentugu húsnæði.
Landspítalinn er sjúkrahús allra Íslendinga og hlutverk hans sem slíks er prípætt - pjónusta við sjúklinga, menntun heilbrigðisstétta og rannsóknir. Náin tengsl eru á milli pessara pátta. Til að ná góðum árangri í umönnun sjúkra, er mikilvægt að geta sinnt öflugu rannsóknar- og próunarstarfi með háskólum og fyrirtækjum á sviði lífvísinda og tækni. Með peim hætti getum við laðað til okkar nemendur og öflugt starfsfólk og aukið gæði í heilbrigðispjónustunni.

Vatnsmýrarsvæðið er mikilvægur staður í áframhaldandi próun spítalans sem pjónustustofnunar enda eiga háskólasjúkrahús og pekkingarstofnanir, meðal annars á Vatnsmýrarsvæðinu, í sífellt fjölbreyttara samstarfi. Pverfagleg starfsemi eykst hratt, bæði milli greina innan háskóla, innan sjúkrahúsa og í samstarfi atvinnulífs og sjúkra- og menntastofnana. Má par til dæmis nefna hversu mikilvægu hlutverki tölvutækni, tæknifræði og verkfræði gegna í próun heilbrigðisvísinda auk læknisfræði og lífvísinda almennt. Bygging nýrra húsa á Landspítalalóð og endurbætur eldra húsnæðis spítalans við Hringbraut gegnir lykilhlutverki til að pjóðarsjúkrahúsið geti áfram sinnt hlutverki sínu.

Stöndum saman um nauðsynlegar endurbætur á Landspítala. Leitum leiða til að fjármagna petta verkefni og hrinda pví í framkvæmd. Undirbúningsvinnunni er lokið. Рað er kominn tími til aðgerða. Íslenska pjóðin parf á pví að halda.

Hospital for all of us in Iceland Thorkell Sigurlaugsson Executive director, Finance and facility management, Reykjavik University 